\title{
Dried rose (Rosa damascena Mill.) dreg: an alternative litter material in broiler production
}

\author{
S. Aktan ${ }^{1 \#}$ and O. Sagdic ${ }^{2}$ \\ ${ }^{1}$ Department of Animal Science, Faculty of Agriculture, University of S. Demirel, 32260, Isparta, Turkey \\ ${ }^{2}$ Department of Food Engineering, Faculty of Agriculture, University of S. Demirel, 32260, Isparta, Turkey
}

\begin{abstract}
The present study was carried out to determine the effects of using dried rose dreg (DRD) as an alternative litter material for broiler performance and microbiological characteristics of litter. A total of 225 day-old broiler chicks was raised on pine wood shavings (PS), DRD and PS+DRD until 42 days. The effects of litter material on broiler performance and FCR did not differ. At 42 days the effects of DRD on microbiological characteristics differed statistically from the other treatments. Total aerobic mesophilic bacteria (TAMB), Enterococci, Enterobactericeae and Staphylococcus aureus counts were decreased in the DRD group at 42 days. These results indicate that DRD can be used as an alternative litter material to control microbial characteristics without a negative effect on broiler performance.
\end{abstract}

Keywords: Broiler, dried rose dreg, litter, performance

\#Corresponding author. E-mail: saktan@ziraat.sdu.edu.tr

\section{Introduction}

There are numerous challenges presented when attempting to reduce human exposure to foodborne pathogens, especially when these pathogens are associated with foods of animal origin. Reduction of pathogens on farms is necessary if cleaner products are expected after processing. However, few effective intervention methods are currently available for use in poultry production. Several poultry litter treatments such as aluminium sulphate (alum) and sodium bisulphate, intended primarily for use in reducing ammonia levels, promoting animal health or inhibiting mould growth, do exist. Since many of these products are acidic compounds it is reasonable to expect that proper application could significantly lower $\mathrm{pH}$ and water activity of the poultry litter, conditions that directly affect the survival rate of microorganisms present in the litter (Line, 2002).

It is well known that ammonia build-up adversely affects body weight, feed conversion and survival rate in poultry and is also harmful to farm labourers. Acidic poultry litter treatments reduce volatile ammonia by reducing the $\mathrm{pH}$, which shifts the $\mathrm{NH}_{4}{ }^{+} / \mathrm{NH}_{3}$ equilibrium towards $\mathrm{NH}_{4}{ }^{+}$(Charles \& Payne, 1966; Donham, 1996; Line, 2002). Significant reductions in litter $\mathrm{pH}$ and exposure to $\mathrm{pH}$ levels below 4.5 would be expected to be bacteriostatic or bactericidal for Salmonella and Campylobacter (Hill et al., 1995; Line, 2002).

Rose (Rosa damascena Mill.) is a species being used to produce attar of rose by distilling volatile oils from the flowers. Turkey is amongst the leading producers of rose oil. The rose oil is produced mainly in Isparta, Burdur and Denizli provinces. One unit weight of rose oil distilled gives about 2 units of residue on a wet basis. The content of solids in the wet residue is approximately $10 \%$, consisting of $90 \%$ organic matter (Tosun et al., 2002). It was reported that some fresh and spent flower extracts and essential oils obtained from plants such as Rosa damascena, Mentha piperita, Origanum onites, Juniperus exalsa, Thymbra spicata, Satureja cuneifolia have antioxidant, antimicrobial and antibacterial activities (Aridogan et al., 2002; Baydar et al., 2004; Ozkan et al., 2004).

The present study was conducted to determine the effects of using dried rose dreg alone or equally mixed with pine wood shavings as an alternative litter material in broiler production on broiler performance and microbiological composition of the litter during the production period.

\section{Materials and Methods}

A total of 225 day-old Cobb 500 broiler chicks was used for this study conducted at the S. Demirel University, Atabey (Isparta) in Turkey. Chicks were randomly distributed into three trial groups with three replicates of each group. In the control group, broilers were raised on pine wood shavings (PS). In the second and third groups, broilers were raised on DRD and equally mixed PS and DRD litter material (PS+DRD), 
respectively. All the broilers were housed in nine enclosed pens with a stocking density of approximately 14 birds $/ \mathrm{m}^{2}$ for 42 days. The broilers received food and water ad libitum.

Litter $\mathrm{pH}$ levels were monitored weekly by placing about $25 \mathrm{~g}$ samples (three replicates for each group) in $125 \mathrm{~mL}$ deionised water and measuring the $\mathrm{pH}$ with a $\mathrm{pH}$ meter (WTW PH526, Germany). Litter samples were aseptically collected to determine microbiological characteristics at 0,21 and 42 days. Then, $10 \mathrm{~g}$ of litter samples were homogenized with $90 \mathrm{~mL}$ of a sterile solution of $0.85 \%(\mathrm{w} / \mathrm{v})$ sodium chloride at $45{ }^{\circ} \mathrm{C}$. Decimal dilutions $\left(10^{-1}, 10^{-2}, 10^{-3}\right.$ or $\left.10^{-4}\right)$ of litter samples were prepared in $9 \mathrm{~mL}$ sterile $\mathrm{NaCl}$ $(0.85 \%)$ to count pathogenic microorganisms.

Total aerobic mesophilic bacteria (TAMB) were enumerated on plate count agar following the pourplate method and incubated at $30^{\circ} \mathrm{C}$ for $72 \mathrm{~h}$. Salmonella and Shigella were grown on S.S. agar incubated at $37^{\circ} \mathrm{C}$ for $48 \mathrm{~h}$. Enterobacteriaceae and coliforms were determined on Violet Red Bile Glucose agar (VRBG) and Violet Red Bile Lactose (VRBL), respectively and incubated at $37{ }^{\circ} \mathrm{C}$ for $24-48 \mathrm{~h}$. Staphylococcus aureus was enumerated by plating on Baird Parker egg yolk tellurite medium following the surface-plate method, and incubated at $37{ }^{\circ} \mathrm{C}$ for $48 \mathrm{~h}$. Black colonies with cream-white halo and with a clear zone around it were recorded as $S$. aureus. Yeast and moulds were determined on potato dextrose agar acidified with $10 \%$ lactic acid following the surface plate method, and incubated at $25{ }^{\circ} \mathrm{C}$ for four days. Enterococci were counted on KF Streptococcal agar incubated at $30{ }^{\circ} \mathrm{C}$ for three days (APHA, 1995; Sparks, 1996). The microbial counts were determined as colony forming units (cfu) per gram of the samples. The results of microbiological analyses are shown as log cfu/g. All analyses were conducted in duplicate. Statistical analyses of the data were performed using an analysis of variance with separation of the means by the Duncan Multiple Range test (Duzgunes et al., 1987). Statements of statistical differences were based on P $\leq$ 0.05 , unless otherwise stated. All analyses were performed using SPSS ${ }^{\circledR} 10.0$ computer software (SPSS Inc., Chicago, USA 1999).

\section{Results and Discussion}

Live weights and feed conversion ratio (FCR) values are shown in Table 1 and Table 2, respectively.

Table 1 Mean weekly body weights, ( \pm \pm s.e.) of the chickens raised on different litter material

\begin{tabular}{cccc}
\hline \multirow{2}{*}{ Weeks } & \multicolumn{3}{c}{ Litter material } \\
\cline { 2 - 4 } & \multicolumn{1}{c}{ PS } & DRD & PS+DRD \\
\hline 0 & $41.1 \pm 0.62$ & $42.1 \pm 0.69$ & $42.1 \pm 0.55$ \\
1 & $120.1 \pm 2.36$ & $126.6 \pm 2.35$ & $123.4 \pm 2.11$ \\
2 & $349.7 \pm 7.10$ & $362.9 \pm 5.78$ & $353.9 \pm 5.51$ \\
3 & $753.0 \pm 13.7$ & $767.4 \pm 11.1$ & $760.4 \pm 10.9$ \\
4 & $1287.0 \pm 23.0$ & $1321.6 \pm 19.9$ & $1299.6 \pm 19.8$ \\
5 & $1874.7 \pm 34.6$ & $1923.6 \pm 31.8$ & $1900.8 \pm 23.6$ \\
6 & $2338.8 \pm 40.4$ & $2394.2 \pm 31.0$ & $2371.1 \pm 31.3$ \\
\hline
\end{tabular}

PS - pine wood shavings; DRD - dried rose dreg

Table 2 Cumulative feed conversion ratios (FCR) (g feed/g weight gain) (mean \pm s.e.) of chickens raised on different litter material

\begin{tabular}{cccc}
\hline \multirow{2}{*}{ Weeks } & \multicolumn{3}{c}{ Litter material } \\
\cline { 2 - 4 } & PS & DRD & PS+DRD \\
\hline $0-1$ & $1.003 \pm 0.072$ & $0.972 \pm 0.033$ & $0.966 \pm 0.033$ \\
$0-2$ & $1.269 \pm 0.049$ & $1.207 \pm 0.031$ & $1.215 \pm 0.015$ \\
$0-3$ & $1.393 \pm 0.046$ & $1.365 \pm 0.008$ & $1.338 \pm 0.007$ \\
$0-4$ & $1.549 \pm 0.029$ & $1.534 \pm 0.019$ & $1.515 \pm 0.005$ \\
$0-5$ & $1.751 \pm 0.040$ & $1.675 \pm 0.011$ & $1.699 \pm 0.009$ \\
$0-6$ & $1.883 \pm 0.031$ & $1.816 \pm 0.010$ & $1.838 \pm 0.008$ \\
\hline
\end{tabular}

PS - pine wood shavings; DRD - dried rose dreg 
Results from Table 1 show that up to 42 days of age the body weights of the chickens did not differ (P $>0.05$ ) between groups. Nevertheless, the broilers raised on DRD were heavier than other litter treatments throughout the trial. Similarly, birds raised on PSD+DRD were found numerically heavier than the birds raised on PS. According to the cumulative FCR comparison in Table 2, there was no statistical difference (P $>0.05$ ) between groups throughout the trial, but the results may be interpreted that FCR was numerically better in DRD litter group than in the other groups.

The microbiological characteristics of litter materials are summarized in Table 3. While initial TAMB and Enterococci counts were lower $(\mathrm{P}<0.001)$ in the PS group than in the DRD and PS+DRD groups, it was found that the lowest $(\mathrm{P}<0.05)$ TAMB and Enterococci counts were in the DRD group at 42 days. Similarly, the Enterobactericeae count did not differ until day 21, when there was a lower $(\mathrm{P}<0.05)$ Enterobactericeae count in the DRD group at $42 \mathrm{~d}$ than in the other groups. The $S$. aureus count differed (P $<0.05)$ between groups only at 42 days. While initial total yeast and mould counts were found lower $(\mathrm{P}<$ 0.001) in PS group, it was found at a numerically lower count in the DRD group at 42 days than in the other groups. As an alternative litter material, DRD had antimicrobial and antibacterial effects at 42 days, presumably due to the essential oils. This is in agreement with other researchers (Aridogan et al., 2002; Baydar et al., 2004; Ozkan et al., 2004).

Table 3 Microbiological characteristics in the different litter material, $\log$ cfu/g (mean \pm s.e.)

\begin{tabular}{|c|c|c|c|c|}
\hline \multirow{2}{*}{ Microbial result } & \multirow{2}{*}{ Litter Material } & \multicolumn{3}{|c|}{ Days } \\
\hline & & $0^{*}$ & 21 & $42^{* *}$ \\
\hline \multirow{3}{*}{$\begin{array}{l}\text { Total aerobic mesophilic } \\
\text { bacteria }\end{array}$} & PS & $4.50 \pm 0.03^{c}$ & $9.91 \pm 0.07$ & $7.72 \pm 0.07^{\mathrm{a}}$ \\
\hline & DRD & $6.08 \pm 0.17^{\mathrm{b}}$ & $9.58 \pm 0.40$ & $7.13 \pm 0.25^{\mathrm{b}}$ \\
\hline & PS+DRD & $6.89 \pm 0.08^{\mathrm{a}}$ & $9.96 \pm 0.04$ & $7.82 \pm 0.04^{\mathrm{a}}$ \\
\hline \multirow{3}{*}{ Salmonella-Shigella } & PS & - & $3.80 \pm 0.03$ & - \\
\hline & DRD & - & $3.85 \pm 0.03$ & - \\
\hline & PS+DRD & - & $3.88 \pm 0.05$ & - \\
\hline \multirow{3}{*}{ Enterobactericeae } & PS & - & $5.72 \pm 0.13$ & $1.34 \pm 0.18^{\mathrm{a}}$ \\
\hline & DRD & - & $5.48 \pm 0.09$ & $0.56 \pm 0.31^{b}$ \\
\hline & PS+DRD & - & $5.90 \pm 0.11$ & $1.46 \pm 0.09^{\mathrm{a}}$ \\
\hline \multirow{3}{*}{ Coliforms } & PS & - & $4.04 \pm 0.10$ & - \\
\hline & DRD & - & $3.97 \pm 0.14$ & - \\
\hline & PS+DRD & - & $3.94 \pm 0.02$ & - \\
\hline \multirow{3}{*}{ E. coli } & PS & - & $3.08 \pm 0.07$ & - \\
\hline & DRD & - & $2.97 \pm 0.14$ & - \\
\hline & PS+DRD & - & $2.83 \pm 0.09$ & - \\
\hline \multirow{3}{*}{ Enterococci } & PS & 0 & $4.69 \pm 0.15$ & $7.39 \pm 0.10^{\mathrm{a}}$ \\
\hline & DRD & $3.56 \pm 0.06^{\mathrm{a}}$ & $4.43 \pm 0.17$ & $6.54 \pm 0.20^{b}$ \\
\hline & PS+DRD & $3.34 \pm 0.06^{\mathrm{a}}$ & $4.59 \pm 0.12$ & $7.42 \pm 0.24^{\mathrm{a}}$ \\
\hline \multirow{3}{*}{ S. aureus } & PS & - & $5.46 \pm 0.09$ & $0.99 \pm 0.08^{a}$ \\
\hline & DRD & - & $5.49 \pm 0.05$ & $0.31 \pm 0.31^{\mathrm{b}}$ \\
\hline & PS+DRD & - & $5.35 \pm 0.09$ & $1.29 \pm 0.04^{\mathrm{a}}$ \\
\hline \multirow{3}{*}{ Yeasts and moulds } & PS & $3.20 \pm 0.09^{b}$ & $7.69 \pm 0.16$ & $7.26 \pm 0.30$ \\
\hline & DRD & $5.48 \pm 0.05^{\mathrm{a}}$ & $7.52 \pm 0.07$ & $6.29 \pm 0.32$ \\
\hline & PS+DRD & $5.31 \pm 0.03^{\mathrm{a}}$ & $7.30 \pm 0.21$ & $6.84 \pm 0.07$ \\
\hline
\end{tabular}

$* \mathrm{P}<0.001, * * \mathrm{P}<0.05$

${ }^{\mathrm{a}-\mathrm{c}}$ Within columns, within litter materials, means with common superscripts do not differ $(\mathrm{P}>0.05)$ 
In Figure 1 the weekly $\mathrm{pH}$ values of litter materials are presented. While initially all the litter material groups were acidic, it was found that both the DRD and PS+DRD groups were acidic at day 21, but only the DRD group was acidic at day 42.

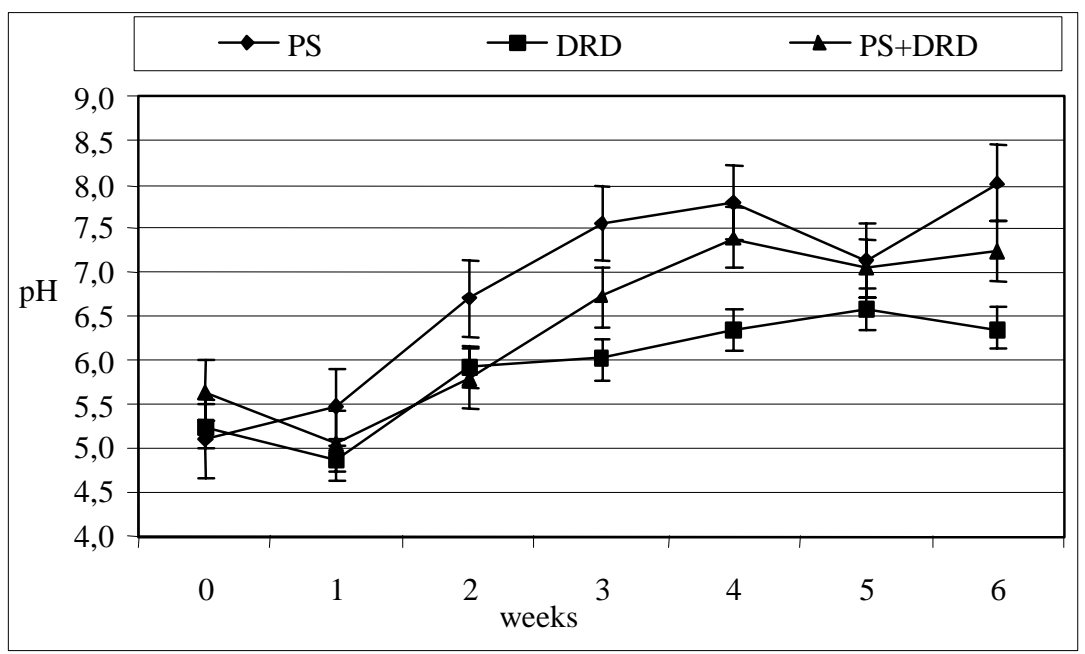

Figure 1 Weekly pH levels (with s.e. bars) of different litter material in the pens of boilers up to an age of 42 days

\section{Conclusion}

It was observed that the use of DRD as a litter material for broilers resulted in a decrease in the occurrence of pathogen microorganisms especially at the last stages of the finishing period. It is highly likely that this might have resulted from both the essential oils content in DRD and the effect of a decrease in the $\mathrm{pH}$ level of litter towards the last stages of the finishing period. These results showed that DRD as an industrial waste material in Turkey could be recycled and used as an enriched organic fertilizer in crop production, as well as decreasing the amount of pathogenic microorganisms in poultry production. Moreover, the essence of roses accumulated in the poultry houses provided less of a nuisance smell in the environment for workers than the wood shavings. The present study showed that as an alternative litter material, DRD caused antimicrobial and antibacterial effects during broiler production. However, further research with inoculated litters and for common use with not only DRD but also rose and other herbal species extracts are required to clarify the antimicrobial and antibacterial effects of the essential oils.

\section{References}

APHA, 1995. Standard methods for the examination of water and wastewater (19th ed.). American Public Health Association (APHA), American Water Works Association (AWWA), Water Environment Federation (WEF).

Aridogan, B.C., Baydar, H., Kaya, S., Demirci, M., Ozbasar, D. \& Mumcu, E., 2002. Antimicrobial activity and chemical composition of some essential oils. Arch. Pharm. Res. 25, 860-864.

Baydar, H., Sagdic, O., Ozkan, G. \& Karadogan, T., 2004. Antibacterial activity and composition of essential oils from Origanum, Thymbra and Satureja species with commercial importance in Turkey. Food Control 15, 169-172.

Charles, D.R. \& Payne, C.G., 1966. The influence of graded levels of atmospheric ammonia on chickens. Br. Poult. Sci. 7, 177-187.

Donham, K.J., 1996. Air quality relationships to occupational health in the poultry industry. Pages 24-28 in Proc. 1996 National Poultry Waste Management Symposium. Auburn University Printing Service, Auburn, AL, USA.

Duzgunes, O., Kesici, T., Kavuncu, O. \& Gurbuz, F., 1987. Arastirma ve Deneme Metodlari. (In Turkish) Ankara Üniversitesi Ziraat Fakültesi Yayinlari, No: 1021, Ankara.

Hill, C.B., Driscoll, O. \& Booth, I., 1995. Acid adaption and food poisoning microorganisms. Int. J. Food Microbiology 28, 245-254. 
Line, J.E., 2002. Campylobacter and Salmonella populations associated with chickens raised on acidified litter. Poult. Sci. 81, 1473-1477.

Ozkan, G., Sagdic, O., Gokturk Baydar, N. \& Baydar, H., 2004. Study on antioxidant and antibacterial activities of fresh and spent Rosa damascena flower extracts. Food Sci. Techol. Int. (in the press).

Sparks, D.L., 1996. Methods of soil analysis: Part 3, Chemical methods and processes. Soil Sci. Soc. Am. Book Series 5, SSSA, Madison, WI.

SPSS $^{\circledR} 10.0$ Computer Software (1999). SPSS Inc., Headquarters, 233 s., Wacker Drive, Chicago, Illinois 60606, USA.

Tosun, I, Gonullu, M.T. \& Gunay, A., 2002. Anaerobic digestion of residues from rose oil production. ISWA 2002 World Environmental Congress and Exhibition, 8-12 July, Istanbul. pp.703-710. 